\title{
Tactile design of manipulator fingers based on fingertip/textile friction-induced vibration stimulations
}

\author{
DOI: 10.35530/IT.071.01.1354
}

\section{ABSTRACT - REZUMAT}

\section{Tactile design of manipulator fingers based on fingertip/textile friction-induced vibration stimulations}

Textile-like soft and flexible products are widely used in our daily life. Understanding the relationship between the tactile sensations of textiles and the tactile stimuli is essential for developing humanoid robot's finger haptic system, especially for certain kind of robot systems such as service robots and exploratory robots. This paper built a frequency space that can qualitatively represent a roughness sensation of textiles by a developing independently random match algorithm in combination with neurophysiological features of cutaneous mechanoreceptors. The experimental results show that the sum of amplitude in frequency range between 18 and $118 \mathrm{~Hz}$ can effectively describe the roughness sensory of textile with accuracies of $98.5 \%$. In other words, by applying the sum of amplitude in frequency range between 18 and $118 \mathrm{~Hz}$ could successfully match roughness sensation of textiles, and it will help engineer of humanoid robot design manipulator finger haptic system in textile field.

Keywords: vibration, frequency space, roughness sensation, textile

\section{Proiectarea tactilă a degetelor pentru manipulare bazată pe stimularea vibrațiilor induse de vârful degetului/frecarea materialului textil}

Produsele ușoare și flexibile precum materialele textile sunt utilizate pe scară largă în viața noastră de zi cu zi. Înțelegerea relației dintre senzațiile tactile ale materialelor textile și stimulii tactili este esențială pentru dezvoltarea sistemului haptic al degetelor robotului umanoid, în special pentru anumite tipuri de sisteme robotice, precum roboții pentru manipulare și roboții de explorare. Această lucrare a dezvoltat un spațiu de frecvență, care poate reda calitativ senzația de rugozitate a materialelor textile, prin elaborarea unui algoritm independent aleatoriu ce combină caracteristicile neurofiziologice ale mecanoreceptorilor cutanați. Rezultatele experimentale arată că suma amplitudinii în intervalul de frecvență cuprins între 18 și $118 \mathrm{~Hz}$ poate descrie în mod eficient rugozitatea senzorială a materialelor textile cu o precizie de 98,5\%. Cu alte cuvinte, aplicând suma amplitudinii în intervalul de frecvență cuprins între 18 și $118 \mathrm{~Hz}$, s-ar putea obține cu succes senzația de rugozitate a materialelor textile și va ajuta la dezvoltarea sistemului haptic al degetelor robotului umanoid pentru domeniul textil.

Cuvinte-cheie: vibrație, domeniu de frecvență, senzație de rugozitate, material textil

\section{INTRODUCTION}

Tactile sensing is an important ability for a humanoid robot which interacts in a complex environment. It can be achieved by deriving a spatial vibration signal from the fingertip sliding across material's surface and then generating a proper stimulating signal to the manipulator fingers [1-2]. In this context, to sense and evaluate materials characteristics, understanding the relationship between tactile sensations and vibration stimuli is critical. Especially, for textile products that are widely used in our daily life, the tactile system of robots should have the ability to identify and discriminate textile materials with acceptable accuracy.

On the other hand, neurophysiologists and psychologists have acknowledged the importance of vibrotactile signals in understanding human tactile perception. It has been observed that four cutaneous mechanoreceptors can give us the ability to estimate tactile qualities in fingertip. They are SAI units (Merkel cells), SAll units (Ruffini corpuscles), RA units (Meissner corpuscles) and PC units (Pacinian corpuscles), respectively. Among them, SAI units are sensitive to low-frequency vibration, frequency range from 2 to $16 \mathrm{~Hz}$. These units transmit the information about pressure and structure of objects to the brain. The RA units are most sensitive to tangential force and can be easily excited by the frequency range between 2 and $60 \mathrm{~Hz}$. The PC units, however, are very sensitive to mechanical transient vibrations in high frequencies, in the range of 40 to $500 \mathrm{~Hz}$. The SAll units are sensitive to the lateral stretching and the sensitive frequency range is from 100 to $500 \mathrm{~Hz}$ [3-4].

Some study results have indicated that the intensity and energy density of vibration signals have great 
influence on the sensations of roughness/smoothness [5]. And the vibration spectrum distribution have an effect on the sensation of softness [6]. Moreover, some researchers set frequency domain according to receptor characteristics to analysis tactile sensation but they hypothesis that the frequency bands are independent [3-4, 7]. However, although a tactile sensation is related to the vibration signals, an investigation of vibration frequency domain between the provided tactile stimuli and the achieved perception is still mysterious. Especially, for textile materials composing of fibers and yarns, the friction-induced vibration signals of textile and fingertip are more complex and include vibration components from high frequency to low frequency. Different vibration domain contains different material characteristics. Among them, the high frequency components depend on the surface hairiness and microscopic textures, and the low frequency signals are due to the main surface pattern textures of textiles. So to understand how vibration frequency domains affect textile tactile perception is considered a key to improve the communication efficiency in the design of manipulator fingers in the textile field.

This paper uses random matching algorithm to seek a vibration frequency space which can qualitatively represent roughness sensation. Here the frequency domain of fingertip/textile vibration signal is arbitrarily divided into ten frequency sub-bands, and the amplitude of each divided frequency domain is calculated. Noteworthy, each frequency sub-band is a matrix space. Meanwhile, the sum of amplitude in each frequency domain is used to match roughness sensation of textiles. The well-matched vibration frequency space will efficiently represent the tactile sensation of textile and throw light on a tactile design of manipulator fingers.

\section{EXPERIMENTAL WORK}

\section{Materials and method}

To seek the ranges of frequency to predict roughness sensation, four random fabrics which are obvious surface textures were chosen as experimental materials in our experiments. The specification parameters were shown in the table 1, and their stereoscopic microscope images were presented in figure 1.

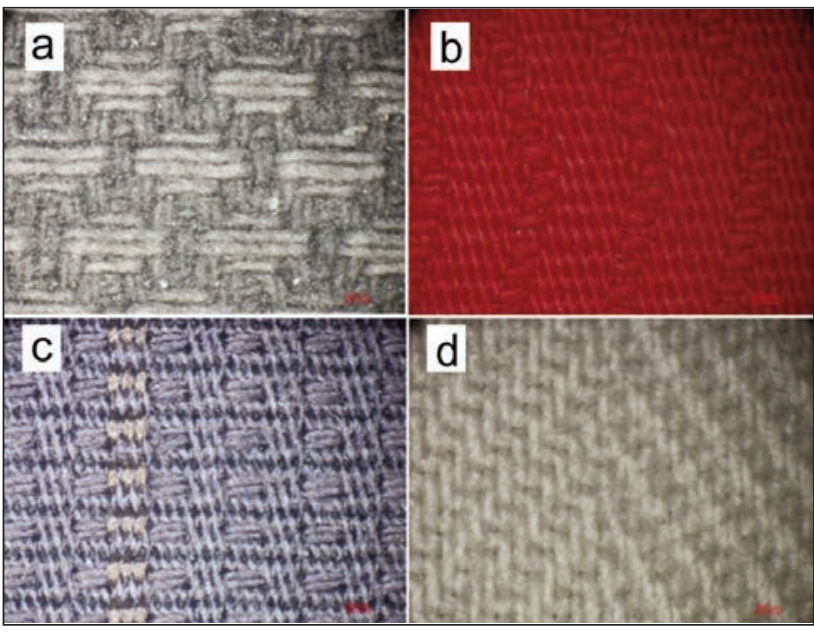

Fig. 1. Four random fabrics

\section{Evaluation conditions}

Four fabrics were preconditioned for $24 \mathrm{~h}$ before evaluation and tests were performed in standard atmosphere $\left(20 \pm 2^{\circ} \mathrm{C}\right.$ and $65 \pm 5 \%$ relative humidity). The sensory evaluation method refers to AATCC Guidelines for the Subjective: Evaluation of Fabric Hand [8]. To obtain reliable results, strict controlled procedures have been implemented and the evaluation has been performed in blind condition for replicating thrice. Subjects were eighteen men and twelve women, aged from 18 to 24 , and most of them were textile background.

\section{Friction-induced vibration signal acquisition}

To control the applied normal load and the relative sliding velocity, the finger is fixed and the experimental samples are moved from left to right at a constant speed. A low mass $(0.8 \mathrm{~g})$ accelerometer (Model $356 \mathrm{~A} 01)$ with high sensitivity $\left(1 \mathrm{mV} / \mathrm{mm} / \mathrm{s}^{2}\right)$ is applied on the finger nail to measure global vibrations (figure $2, a)$. Notice, the mass of accelerometer has not effect on the signal [9]. At the same time, the force transducers (500 $\mathrm{mV} / \mathrm{lb}$, Model 208C01) are placed below the sample holding platform for monitoring the global contact force. During sliding process, the normal applied load is about $0.8 \mathrm{~N}$ and the scanning speeds are $10 \mathrm{~mm} / \mathrm{s}$ for textile. This is because the scanning speeds are commonly in the range $10 \mathrm{~mm} / \mathrm{s}$ to $50 \mathrm{~mm} / \mathrm{s}$, higher for hard objects and lower for textile [10-12].

\begin{tabular}{|c|c|c|c|c|}
\hline \multicolumn{5}{|c|}{ SPECIFICATION PARAMETERS } \\
\hline No. & $\begin{array}{c}\text { Warp } \mathbf{x} \text { Weft density } \\
(\text { yarns/10 cm) }\end{array}$ & Count (Ne) & Composition & Weight $\left(\mathbf{g} / \mathbf{m}^{2}\right.$ ) \\
\hline 1 & $95 \times 64$ & $16 \times 16$ & Cotton $100 \%$ & 244 \\
\hline 2 & $65 \times 100$ & $40 \times 32$ & Cotton $100 \%$ & 208 \\
\hline 3 & $175 \times 108$ & $40+150 \mathrm{D} \times 40$ & Cotton $95.5 \% /$ Terylene $4.5 \%$ & 175 \\
\hline 4 & $78 \times 59$ & $12 \times 8$ & Cotton $100 \%$ & 341 \\
\hline
\end{tabular}




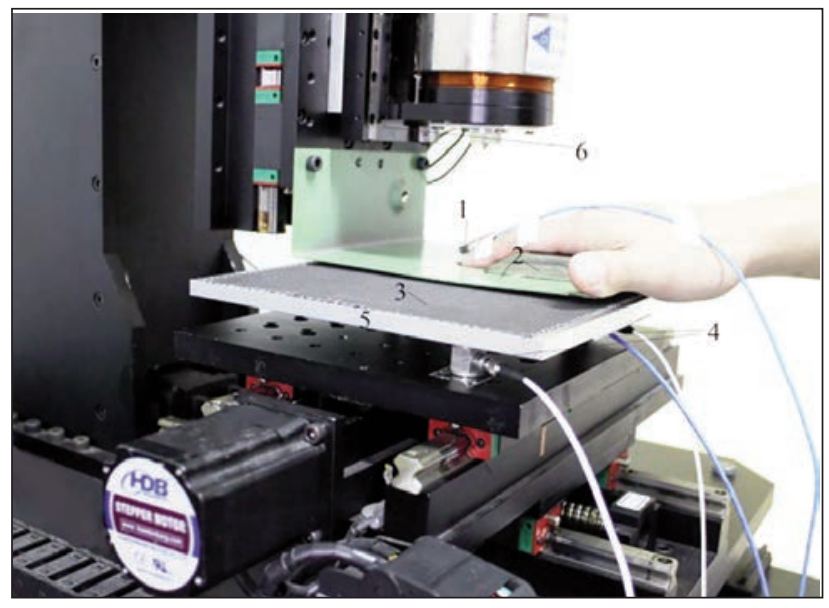

a

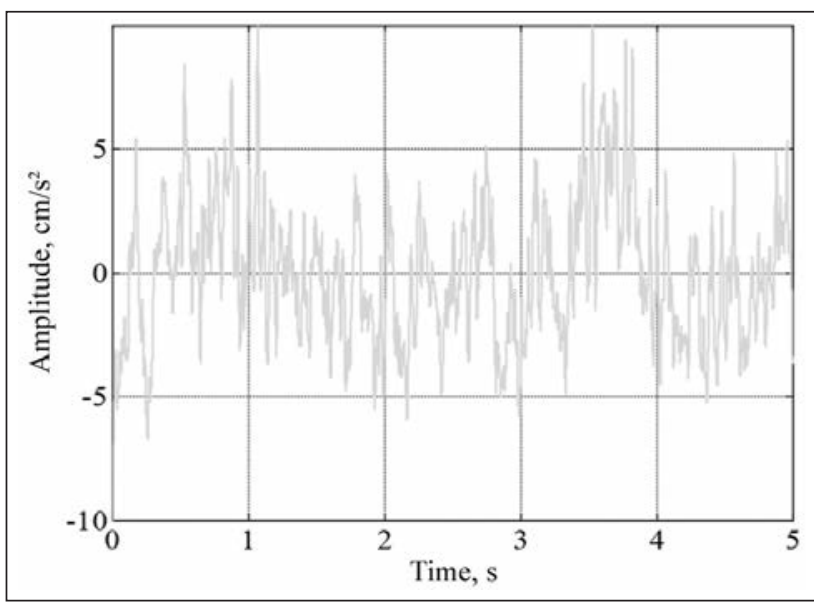

b

Fig. 2. Signal acquisition: a - Schematic diagram: 1 - Accelerometer, 2 - finger supports, 3 - textile sample, 4 - force transducers, 5 - base plate, $6-3 \mathrm{D}$ motion control platforms; $b$ - vibration signal of sample $\mathrm{A}$

Frequency space of friction-induced vibration signals

Using the random matching algorithm, the frequency bands of fingertip/textile vibration signal were divided arbitrarily into ten sub-bands with different width. Considering the frequency response characteristics of the mechanical receptors [3,13], narrow bandwidths are set for the lower frequency bands, whereas wide bandwidths are used for higher frequency bands.

Here, $f_{0}=0, f_{10}=500$, and $f_{i}$ values are natural numbers between 0 and 500 .

$$
\begin{aligned}
& f_{1}=f_{0}+\{1,2, \ldots, 10\} \\
& f_{2}=f_{1}+\{1,2, \ldots, 20\} \\
& f_{3}=f_{2}+\{1,2, \ldots, 20\} \\
& f_{4}=f_{3}+\{5,10, \ldots, 50\} \\
& f_{5}=f_{4}+\{5,10, \ldots, 50\} \\
& f_{6}=f_{5}+\{5,10, \ldots, 50\} \\
& f_{7}=f_{6}+\{10,20, \ldots, 100\} \\
& f_{8}=f_{7}+\{10,20, \ldots, 100\} \\
& f_{9}=f_{8}+\{10,20, \ldots, 100\}
\end{aligned}
$$

Meanwhile, the sum of the amplitude spectra within each of above sub-bands was calculated. The sum of the amplitudes in the $j_{\text {th }}$ sub-band for material $i$ was determined as follows:

$$
a_{i j}=\int_{f_{j-1}}^{f_{j}} a_{i}(f) d f
$$

where $f$ and $a_{i}(f)$ are the frequency and amplitude, respectively.

And then, a search procedure is made for all of subband widths $\left(f_{0}-f_{10}\right)$ to find an optimized match between the vibration frequency space and roughness perception.

\section{RESULTS AND DISCUSSION}

\section{Roughness sensation scores}

To avoid the personal reference difference of each assessor's score, the tactile evaluation data was normalized firstly, the Grubbs tests are performed to reject the abnormal value, which were probably affected by accidental factors in subjective experiment such as fatigue etc. The magnitude estimation method was used to quantify tactile roughness of four fabrics, and the scores are shown in figure 3.

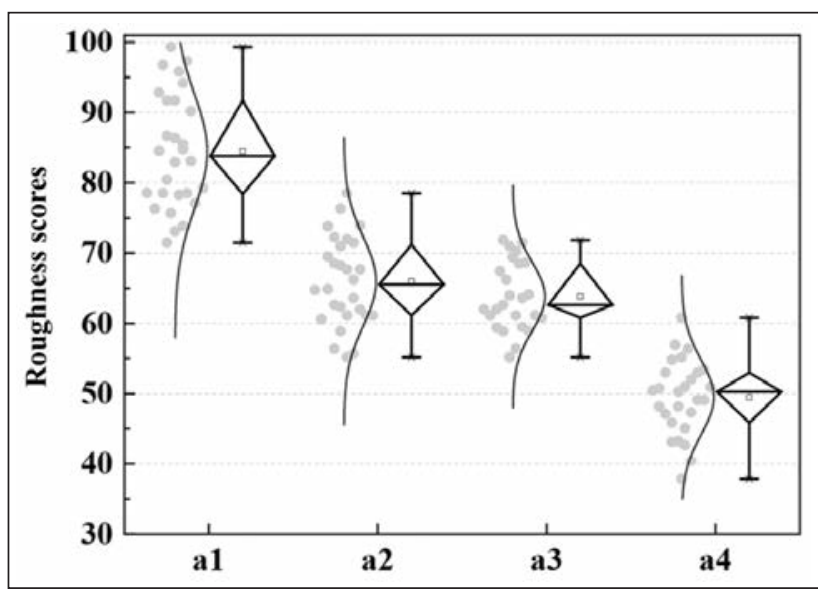

Fig. 3. Tactile roughness of four random fabrics

\section{Frequency sub-bands}

The random matching algorithm is used to calculate the frequency space, all of frequency domains are shown in table 2. It is noteworthy that each sub-band is a matrix. The size of matrix is the number of each frequency sub-bands. Next, the sum of acceleration amplitude in each of frequency sub-bands is calculated according to Equation (1). At the same time, the amplitude of each the frequency sub-band is imported in to a three-dimensional space $(500 \mathrm{~Hz} \times 500 \mathrm{~Hz}$ $\times$ Amplitudes). In this way, the contour of AmplitudeFrequency shows the amplitude distribution in each frequency space, as shown in figure 4.

In figure 4, the brighter color illustrates the bigger amplitude. Interestingly, the main amplitude is mainly distributed within $0-100 \mathrm{~Hz}$. But it is still not clear which frequency sub-band can influence the roughness sensation. Some researchers have concluded 


\begin{tabular}{|c|c|c|c|c|}
\hline \multicolumn{1}{|c|}{ FREQUENCY DOMAIN } \\
\hline$f_{0}-f_{1}$ & $f_{1}-f_{2}$ & $f_{2}-f_{3}$ & $f_{3}-f_{4}$ & \multicolumn{1}{c|}{$f_{4}-f_{5}$} \\
\hline \multirow{3}{*}{$(0-10)$} & $\left(\begin{array}{ccc}1 & \cdots & 21 \\
\vdots & \ddots & \vdots \\
10 & \cdots & 30\end{array}\right)$ & $\left(\begin{array}{ccc}2 & \ldots & 22 \\
\vdots & \ddots & \vdots \\
30 & \cdots & 50\end{array}\right)$ & $\left(\begin{array}{ccc}3 & \ldots & 53 \\
\vdots & \ddots & \vdots \\
50 & \ldots & 100\end{array}\right)$ & $\left(\begin{array}{ccc}8 & \ldots & 58 \\
\vdots & \ddots & \vdots \\
100 & \ldots & 150\end{array}\right)$ \\
\hline & $f_{5}-f_{6}$ & $f_{6}-f_{7}$ & $f_{7}-f_{8}$ & $f_{8}-f_{9}$ \\
\hline & $\left(\begin{array}{ccc}13 & \ldots & 63 \\
\vdots & \ddots & \vdots \\
150 & \cdots & 200\end{array}\right)$ & $\left(\begin{array}{ccc}18 & \ldots & 118 \\
\vdots & \ddots & \vdots \\
200 & \ldots & 300\end{array}\right)$ & $\left(\begin{array}{ccc}28 & \ldots & 128 \\
\vdots & \ddots & \vdots \\
300 & \ldots & 400\end{array}\right)$ & $\left(\begin{array}{ccc}38 & \ldots & 138 \\
4 & \ddots & \vdots \\
400 & \ldots & 500\end{array}\right)$ \\
\hline
\end{tabular}

that the intensity of vibration signals has a great influence on roughness sensation [14]. The random research results for the maximum sum of amplitude in all frequency sub-bands are shown in figure 5 . It shows that the maximum sum of amplitude appears in the range from 18 to $118 \mathrm{~Hz}$. Therefore, it can hypothesize that the sum of amplitude in this frequency sub-band could represent roughness sensation. Moreover, the frequency range conforms with

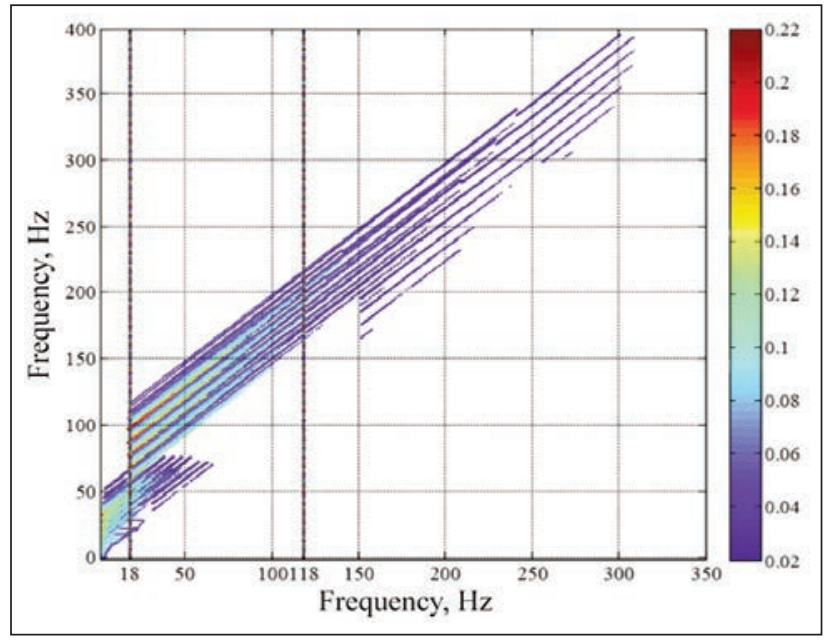

Fig. 4. Contour of Amplitude-Frequency spectrum

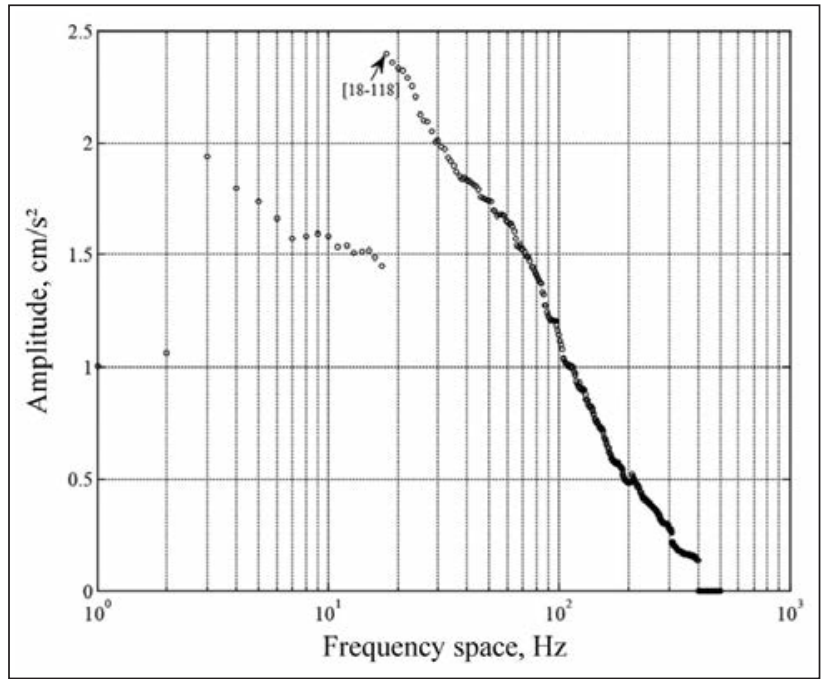

Fig. 5. Acceleration amplitude of different frequency space the neurophysiology results and the width of subband included is narrow previous studies [3-4, 14].

Vibrotactile frequency Space Matched with Roughness sensation scores

To investigate how accurately the vibration signals of textiles could estimate the roughness sensation, the normalization value of amplitude which searched frequency sub-band $(18-118 \mathrm{~Hz})$ is compared with sensory evaluation. Figure 6 shows the comparison of the vibration and estimated value. Inspiringly, the tendency of vibration signals accord with the sensory evaluation but the value is smaller than sensory evaluation. This could be due to signal attenuation in acquisition process. At the same time, we calculate the lin's concordance correlation coefficients [15] of vibration value and sensation evaluation value, the correlation coefficients is 0.985 illustrating that searched frequency sub-band is effective for representing roughness sensation.

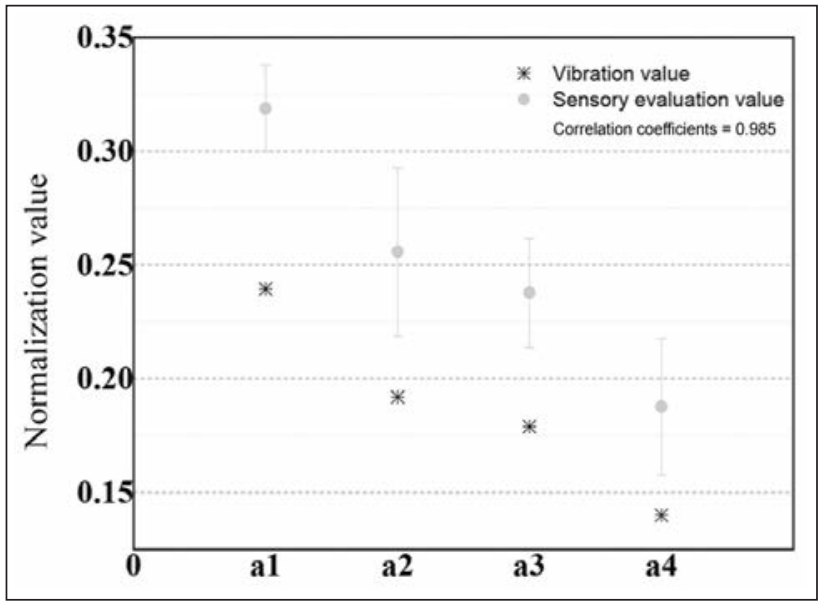

Fig. 6. Vibration and estimated value of four random fabrics

\section{CONCLUSION}

This study matched successfully the fingertip/textile vibration signals and the roughness sensation with a random matching method. The experimental results demonstrate that the sum of amplitude in frequency space between 18 and $118 \mathrm{~Hz}$ can describe the roughness sensory of textile with accuracies of approximately $98.5 \%$, although the intensity of amplitude is 
lower than sensory evaluation. Such a frequency space can be helpful for the analysis and design of humanoid robot's fingers considering that human textural precepts are multidimensional. And it is also meaningful the manipulator fingers to identify and discriminate textile materials.

\section{ACKNOWLEDGEMENTS}

This research was supported by the National Natural Science Foundation under Grant number 51405079, the China Postdoctoral Science Foundation and the Fundamental Research Funds for the Central Universities.

\section{REFERENCES}

[1] Okamoto, S., Ishikawa, S., Nagano, H., Spectrum-based synthesis of vibrotactile stimuli: active footstep display for crinkle of fragile structures, In: Virtual Reality, 2013, 17, 3, 181-191

[2] Sinapov, J., Sukhoy, V., Sahai, R., Vibrotactile Recognition and Categorization of Surfaces by a Humanoid Robot, Robotics, In: IEEE Transactions on, 2011, 27, 3, 488-497

[3] Bensmaia, S., Hollins, M., Yau, J., Vibrotactile intensity and frequency information in the Pacinian system: A psychophysical model, In: Perception \& Psychophysics, 2005, 67, 5, 828-841

[4] Bensmaia, S.J., Hollins, M., The vibrations of texture, In: Somatosensory \& motor research, 2003, 20, 1, 33-43

[5] Hollins, M., Bensmaiea, S.J., The coding of roughness, In: Canadian Journal of Experimental Psychology-Revue Canadienne De Psychologie Experimentale, 2007, 61, 3, 184-195

[6] Bergmann Tiest, W.M., Tactual perception of material properties, In: Vision Research, 2010, 50, 24, 2775-2782

[7] Hollins, M., Lorenz, F., Harper, D., Somatosensory coding of roughness: The effect of texture adaptation in direct and indirect touch, In: The Journal of neuroscience, 2006, 26, 20, 5582-5588

[8] Luible, C., Varheenmaa, M., Magnenat-Thalmann, N., Subjective fabric evaluation, In: Cyberworlds, 2007. CW'07.International Conference', 2007, 285-291

[9] Fagiani, R., Massi, F., Chatelet, E., Experimental analysis of friction-induced vibrations at the finger contact surface, In: Proceedings of the Institution of Mechanical Engineers, Part J: Journal of Engineering Tribology, 2010, 224, 9, 1027-1035

[10] Adams, M.J., Briscoe, B.J., Johnson, S.A., Friction and lubrication of human skin, In: Tribology Letters, 2007, 26, 3, 239-253

[11] Phillips, J.R., Johansson, R.S., Johnson, K.O., Responses of Huamn Mechanoreceptive Afferents to Embossed Dot Arrays Scanned across Fingerpad Skin, In: Journal of Neuroscience, 1992, 12, 3, 827-839

[12] Yoshioka, T., Bensmaia, S.J., Craig, J.C., Texture perception through direct and indirect touch: an analysis of perceptual space for tactile textures in two modes of exploration, In: Somatosensory \& motor research, 2007, 24, $1-2,53-70$

[13] Maeno, T., Kobayashi, K., Yamazaki, N., Relationship between the structure of human finger tissue and the location of tactile receptors, In: Jsme International Journal Series C-Mechanical Systems Machine Elements and Manufacturing, 1998, 41, 1, 94-100

[14] Headley, P.C., Pawluk, D.T.V., Roughness perception of textures on a haptic matrix display, In: Computer Science, Published in IEEE World Haptics Conference, 2011, 221-226

[15] Feng, C., Ma, Y., Tu, X.M., A note on the concordance correlation coefficient, In: Advances \& Applications in Statistics, 2010, 15, 2, 195-205

\section{Authors:}

\section{YANHUI LIU1, GUOQING ZHU²*, ZHENGQIN LIU1 ${ }^{1}$, XINYI HU¹, RUITAO JIANG ${ }^{3}$}

${ }^{1}$ College of Textiles \& Clothing, State Key Laboratory of Bio-Fibers and Eco-Textiles, Qingdao University, 308 Ningxia Road, Qingdao, Shandong, 266071 China

${ }^{2}$ Suzhou Institute of Fiber Inspection, No.69, Wenqu Road, Suzhou, Jiangsu, China

${ }^{3}$ Shanghai Advanced Research Institute, Shanghai Synchrotron Radiation Facitity (SSRF), Chinese Academy of Sciences, 239 zhangheng road, Pudong, Shanghai, China e-mail: chainliuyanhui1@163.com, yan6759141@163.com

*These authors contributed equally to this work and should be considered co-first authors

\section{Corresponding author:}

\section{RUITAO JIANG}

e-mail: yan6759141@163.com 